\title{
Effect of Phragmites australis and Typha latifolia on biofiltration of heavy metals from secondary treated effluent
}

\author{
M. Kumari · B. D. Tripathi
}

Received: 29 May 2013/Revised: 13 September 2013/ Accepted: 7 December 2013/Published online: 8 January 2014

(C) Islamic Azad University (IAU) 2013

\begin{abstract}
The present work deals with a promising approach for the removal of heavy metals from secondary treated wastewater using aquatic plants, which are economic and effective in separating metals from polluted water. Since the conventional sewage treatment processes were inefficient to remove heavy metals from wastewater, batch experiments of Phragmites australis, Typha latifolia and $P$. australis and T. latifolia grown in association and reference (unplanted) were carried out for 15 days of retention time for the removal of copper $(\mathrm{Cu})$, cadmium $(\mathrm{Cd})$, chromium $(\mathrm{Cr})$, nickel $(\mathrm{Ni})$, iron $(\mathrm{Fe})$, lead $(\mathrm{Pb})$, and zinc $(\mathrm{Zn})$ from the secondary treated effluent. Significantly, higher removal of the heavy metals in planted set than the reference revealed role of plants in their removal (analysis of variance, $p<0.05$ ). Higher removal of $\mathrm{Cr}$, $\mathrm{Fe}$, and $\mathrm{Zn}$ $(66.2 \pm 3.5,70.6 \pm 1.2$, and $71.6 \pm 3.9 \%)$ in the combination of the $P$. australis and $T$. latifolia than their individual culture suggested synergistic effect of both the plants in the removal of these metals. Positive relationship was observed between retention time and the removal of heavy metals. Mass balance equation has revealed that the loss of heavy metals in wastewater was equivalent to the net accumulation of heavy metals in plant and loss of heavy metals in natural degradation. $P$. australis showed higher accumulative capacities for $\mathrm{Cu}, \mathrm{Cd}, \mathrm{Cr}, \mathrm{Ni}, \mathrm{Fe}$, and $\mathrm{Pb}$ than those of T. latifolia. The P. australis and T. latifolia grown
\end{abstract}

\section{Kumari}

Pollution Ecology Research Laboratory, Department of Botany,

Banaras Hindu University, Varanasi 221005, India

B. D. Tripathi $(\square)$

Centre for Environmental Science and Technology, Banaras

Hindu University, Varanasi 221005, India

e-mail: tripathibd@gmail.com in association might be utilized for the heavy metal removal in the tropical environment.

Keywords Accumulation - Aquatic plants - Removal · Retention time $\cdot$ Synergistic effect

\section{Introduction}

Heavy metal poses serious threat to aquatic life when present in water bodies. Human consumption of water that is contaminated with heavy metals may cause serious health problems including liver, nerve and bone damage, and the inactivation of vital enzymes that are responsible for metabolic functions. In addition, heavy metals may cause cancer in humans (Ewan and Pamphlett 1996; Moore 1990). Metal-bearing effluents are produced during industrial processing. The removal of toxic heavy metals by conventional processes such as chemical precipitation, flotation, coagulation-flocculation, adsorption, ion exchange, membrane filtration, and oxidation require high capital cost. In addition, these conventional processes generate considerable amounts of sludge and other toxic substances, which require further management (Aziz et al. 2008; Cohen 2006). Therefore, it was imperative to develop alternative technologies that are economical as well as eco-friendly. In recent years, aquatic macrophytes have been used worldwide for the removal of toxic pollutants, including heavy metals and pharmaceutical products from industrial effluent and municipal wastewater (Allende et al. 2011; Augustynowicz et al. 2010; Bonano 2012; Caselles-Osorio and Garcia 2007; Cui et al. 2011; Ghemandi et al. 2007; Hua et al. 2013; Langergraba 2005; Maine et al. 2009; Marchand et al. 2010; Ong et al. 2010; Ranieri et al. 2011; Saeed and Sun 2012; Tang 
et al. 2010; Vymazal 2005; Wen et al. 2010; Wojciechowska and Waara 2011; Xue et al. 2010; Zhang et al. 2012). Main mechanisms of removal of heavy metals by aquatic plants are plant uptake, precipitation and co-precipitation as insoluble salts, and binding to the substrate (Brix 1994; Ranieri et al. 2011). Rhizosphere of aquatic plant provide substrate and supporting media for the growth of microorganisms, which help in the immobilization of heavy metals and uptake by plants (Sekomo et al. 2012; Jacob and Otte 2004; Mench et al. 2009).

The Phragmites and Typha have been reported to remove pollutant from effluents (Badkoubi et al. 1998; Bonanno and Giudice 2010; Ranieri et al. 2011; Ranieri 2012; Reyes-Contreras et al. 2012; Sasmaz et al. 2008; Valipour et al. 2009; Vymazal et al. 2009). These aquatic macrophytes are widely distributed and are known to accumulate efficiently heavy metals and other toxins in their bodies at concentrations well above their surrounding environment (Ye et al. 1997). However, systematic data regarding the removal of heavy metals from secondary treated effluent generated in the tropical cities are scarce. Henceforth, the aim of present study was to assess the removal of heavy metals by $P$. australis and $T$. latifolia in individual and mixed cultures from secondary treated effluent in a tropical city, Varanasi, India.

In the present study, biofiltration units have been used to culture experimental plants. These biofiltration units were composed with a number of vertical PVC pipes. The secondary treated effluent collected from the nearby sewage treatment plant contains organic and inorganic nutrients, which acts as a growth medium for selected wetland plants. Since $P$. australis and $T$. latifolia are wetland plants, they have shown the capacity to survive under hydroponic conditions. In the liquid medium, the PVC pipes act as a support to hold plants. Hence, the present experimental design is comparable to the conditions of plant grown in soil under wetland condition.

\section{Materials and methods}

Batch experiments were configured from August 2011 to October 2011 with $P$. australis and T. latifolia aquatic plants and repeated fortnightly in order to minimize the error.

Secondary treated effluent

Secondary treated effluent was collected fortnightly during August 2011 to October 2011 from the Bhagwanpur sewage treatment plant located in Varanasi city $\left(25^{\circ} 18^{\prime} \mathrm{N}\right.$,
Table 1 Physicochemical properties of the secondary treated effluent

\begin{tabular}{|c|c|c|}
\hline Parameters & Values & $\begin{array}{l}\text { Permissible limits } \\
(\mathrm{CPCB})^{\mathrm{a}}\end{array}$ \\
\hline Temperature $\left({ }^{\circ} \mathrm{C}\right)$ & $23.74 \pm 0.730$ & - \\
\hline $\mathrm{pH}$ & $7.35 \pm 0.209$ & - \\
\hline $\begin{array}{l}\text { Electrical conductivity } \\
\left(\mu \mathrm{S} \mathrm{cm}^{-1}\right)\end{array}$ & $124.82 \pm 9.644$ & - \\
\hline Total alkalinity $\left(\mathrm{mg} \mathrm{L}^{-1}\right)$ & $58.84 \pm 2.474$ & - \\
\hline Acidity $\left(\mathrm{mg} \mathrm{L}^{-1}\right)$ & $16.56 \pm 1.407$ & - \\
\hline Dissolved oxygen $\left(\mathrm{mg} \mathrm{L}^{-1}\right)$ & $0.92 \pm 0.030$ & - \\
\hline $\begin{array}{l}\text { Biochemical oxygen } \\
\text { demand }\left(\mathrm{mg} \mathrm{L}^{-1}\right)\end{array}$ & $35.95 \pm 1.394$ & 30.0 \\
\hline $\begin{array}{l}\text { Chemical oxygen demand } \\
\left(\mathrm{mg} \mathrm{L}^{-1}\right)\end{array}$ & $73.24 \pm 2.475$ & 250.0 \\
\hline Nitrate: nitrogen $\left(\mathrm{mg} \mathrm{L}^{-1}\right)$ & $1.30 \pm 0.190$ & 50.0 \\
\hline $\begin{array}{l}\text { Phosphate: phosphorus } \\
\left(\mathrm{mg} \mathrm{L}^{-1}\right)\end{array}$ & $2.55 \pm 0.228$ & 5.0 \\
\hline Copper $\left(\mathrm{mg} \mathrm{L}^{-1}\right)$ & $0.106 \pm 0.0075$ & 3.0 \\
\hline Cadmium $\left(\mathrm{mg} \mathrm{L}^{-1}\right)$ & $0.091 \pm 0.0009$ & 2.0 \\
\hline Chromium $\left(\mathrm{mg} \mathrm{L}^{-1}\right)$ & $1.212 \pm 0.0540$ & 2.0 \\
\hline Nickel $\left(\mathrm{mg} \mathrm{L}^{-1}\right)$ & $0.078 \pm 0.0033$ & 3.0 \\
\hline Iron $\left(\mathrm{mg} \mathrm{L}^{-1}\right)$ & $1.868 \pm 0.0234$ & 3.0 \\
\hline Lead $\left(\mathrm{mg} \mathrm{L}^{-1}\right)$ & $0.382 \pm 0.0116$ & 0.1 \\
\hline Zinc $\left(\mathrm{mg} \mathrm{L}^{-1}\right)$ & $0.945 \pm 0.0027$ & 5.0 \\
\hline
\end{tabular}

${ }^{\text {a }}$ Permissible limits for discharge in surface water bodies by CPCB

$83^{\circ} 1^{\prime} \mathrm{E}$ ), India. As shown in Table 1, physicochemical properties of treated effluent including temperature (T), $\mathrm{pH}$, electrical conductivity (EC), total alkalinity (T.Alk), acidity (Aci), dissolved oxygen (DO), biochemical oxygen demand (BOD), chemical oxygen demand (COD), nitrate$\mathrm{N}\left(\mathrm{NO}_{3}{ }^{-}-\mathrm{N}\right)$, phosphate-P $\left(\mathrm{PO}_{4}{ }^{3-}-\mathrm{P}\right)$, copper $(\mathrm{Cu})$, cadmium $(\mathrm{Cd})$, chromium $(\mathrm{Cr})$, nickel $(\mathrm{Ni})$, iron $(\mathrm{Fe})$, lead $(\mathrm{Pb})$, and zinc $(\mathrm{Zn})$ were determined using standard methods (APHA et al. 2005). Mean concentrations of $\mathrm{Cu}$, $\mathrm{Cd}, \mathrm{Cr}, \mathrm{Ni}, \mathrm{Fe}$, and $\mathrm{Zn}$ were below the permissible limit for discharge in surface water bodies (CPCB 1993). $\mathrm{Pb}$ concentration was slightly higher than permissible limit. Secondary treated effluent is used for the irrigation of nearby crop fields at Varanasi. These heavy metals were found accumulated in different plant parts and entered in the human food chain, which is a serious threat to human health (Rai and Tripathi 2008). Therefore, in order to avoid bioaccumulation of these heavy metals in the crop plants, present study was conducted as a tertiary treatment process using the wetland plants $P$. australis and $T$. latifolia, which is an economic as well as effective methodology. Since experimental plants absorb heavy metals during the experiment, they cannot be used as fodder or food material, hence, either they may be used for land 
filling or incinerated for heavy metals extraction from the ashes. The plants can also be used to manufacture lowcost paper, so that the metals can be placed in a longer life cycle.

Plant selection

High heavy metal removal capacities of $P$. australis and $T$. latifolia were reported by several previous researchers (Badkoubi et al. 1998; Bonanno and Giudice 2010; Sasmaz et al. 2008; Valipour et al. 2009; Vymazal et al. 2009). Thus, in the present study, P. australis and T. latifolia were selected as test plants. These plants were collected from the nearby wetland, Varanasi, India.

Experimental biofiltration system

\section{Experimental set-up}

Four experimental sets using glass aquarium of $75 \mathrm{~L}$ capacity $(50 \mathrm{~cm}$ length $\times 50 \mathrm{~cm}$ width $\times 30 \mathrm{~cm}$ height $)$ have been used to conduct the experiments. Each of the four sets was fitted with 20 perforated PVC pipes of $30 \mathrm{~cm}$ length and $5 \mathrm{~cm}$ diameter. The perforated PVC pipes were having $27-\mathrm{mm}$ pores for proper liquid exchange. In the present experiment, single plant of $35 \pm 2.1 \mathrm{~cm}$ height and $45.5 \pm 0.5 \mathrm{~g}$ fresh weight of $P$. australis and $45.3 \pm 0.6 \mathrm{~g}$ $T$. latifolia has been selected. One plant of either $P$. australis or T. latifolia was placed in single plastic (PVC) pipe, which was used to support the plant (Fig. 1a). Before the plants were placed in the PVC pipes, they were thoroughly washed with the freshwater. Experimental set 1 consisted of only $P$. australis plants, which were kept at a density of 40 plants $\mathrm{m}^{-2}$. The set 2 consisted of only $T$. latifolia plants, which were kept at a density of 40 plants $\mathrm{m}^{-2}$. In the third set, each of the individual $P$. australis and $T$. latifolia plants was kept in each PVC pipe at a density of 20 plants $\mathrm{m}^{-2}$ (i.e. 20 P. australis plants $\mathrm{m}^{-2}$ and $20 \mathrm{~T}$. latifolia plants $\mathrm{m}^{-2}$ ). In experimental set 4 , no plant was kept. Set 4 was used as control set and kept to assess natural degradation of heavy metals, so that actual removal of heavy metals by the experimental plants grown

a
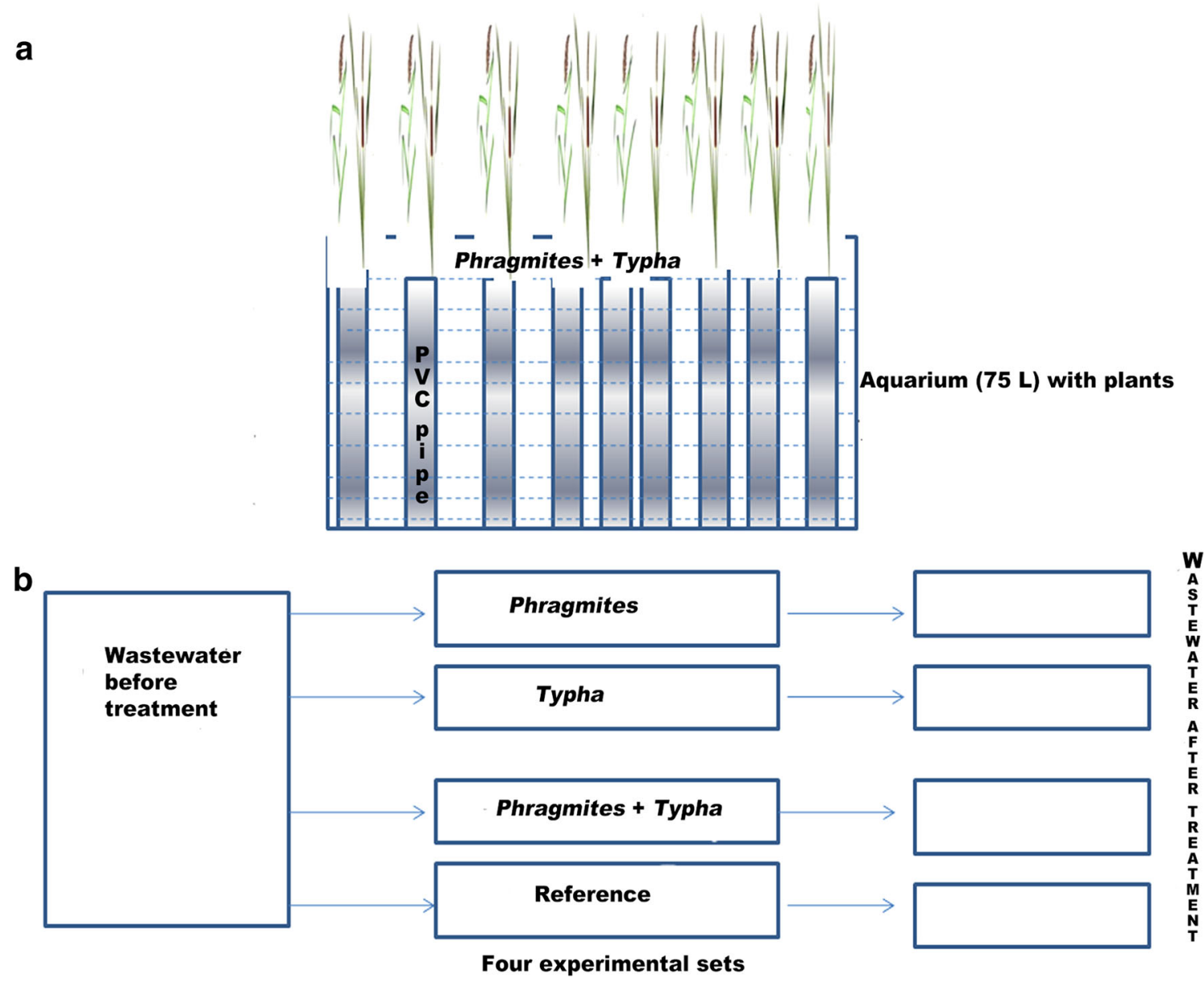

Fig. 1 Experimental design showing a aquarium with $P$. australis and T. latifolia and $\mathbf{b}$ four experimental sets 
individually and in combinations may be evaluated (Fig. 1b). Five replicates of each experimental set were used to minimize experimental error.

\section{Operating conditions}

Biofiltration systems were configured with the $P$. australis and T. latifolia aquatic plants. These systems were operated from August 2011 to October 2011 at fortnightly interval. Fifty litres of the secondary treated effluent was poured into each of the experimental set. The roots and shoots of the plants were thoroughly washed with freshwater before placing in each experimental set. All of the sets were maintained in open conditions with $10 \mathrm{~h}$ of natural sunlight exposure. The water loss through evaporation was maintained by adding an equal amount of double distilled water, and a dilution factor was calculated.

Analytical procedures

\section{Analysis of plant}

Before analysis, the plants were washed properly to remove debris. The washed samples were cut into small pieces and dried to a constant mass in fan-forced oven at $80{ }^{\circ} \mathrm{C}$ for $24 \mathrm{~h}$. The material was then chopped finely and then ground into fine sized powder in agate mortar to facilitate heavy metal analysis. Homogenized material $(5 \mathrm{~g})$ was then digested with a solution mixture of $\mathrm{H}_{2} \mathrm{SO}_{4}: \mathrm{HNO}_{3}: \mathrm{H}_{2} \mathrm{O}_{2} \quad(2: 3: 1)$ at the temperature of $60-70{ }^{\circ} \mathrm{C}$ in a flask on hot plate until white fumes appeared (Kalra 1998). It was further heated till the appearance of clear solution, which indicated complete digestion. The solution was then cooled and maintained up to $25 \mathrm{~mL}$ with double distilled water. The elemental state of $\mathrm{Cu}, \mathrm{Cd}, \mathrm{Cr}, \mathrm{Ni}, \mathrm{Fe}, \mathrm{Pb}$, and $\mathrm{Zn}$ was analysed in digested plant samples at the initial and end of the experiment by atomic absorption spectrophotometer (AAS, PerkinElmer model 2380, USA) as prescribed in Standard Methods (APHA et al. 2005).

\section{Analysis of wastewater}

Heavy metal concentrations in the effluent were analysed initially and at the $6,7,8,9,10,1112,13,14$, and 15 days. Twenty millilitres of wastewater was sampled from each experimental set and analysed for heavy metals. The amount of wastewater removed was replaced with an equal amount of double distilled water. The dilution of heavy metals due to the addition of water was calculated. Water samples were filtered with Whatman filter paper in order to remove suspended particles. The filtrate was digested with a mixed $\mathrm{HCl}: \mathrm{HNO}_{3}(2: 1 \mathrm{v} / \mathrm{v})$ solution on a hot plate until the solution was clear. The samples were then filtered and analysed for $\mathrm{Cu}, \mathrm{Cd}, \mathrm{Cr}, \mathrm{Ni}, \mathrm{Fe}, \mathrm{Pb}$, and $\mathrm{Zn}$ with atomic absorption spectrophotometer (AAS, PerkinElmer model 2380, USA). Certified reference material (CRM) was used to determine the accuracy of the results (APHA et al. 2005).

Per cent removal of heavy metal was calculated by using the following formula: Per cent removal $=\left(1-\mathrm{C}_{\mathrm{f}} /\right.$ $\left.\mathrm{C}_{\mathrm{i}}\right) \times 100 \%$, where $\mathrm{C}_{\mathrm{i}}$ and $\mathrm{C}_{\mathrm{f}}$ are the metal concentrations in the secondary treated effluent before and after treatment, respectively.

\section{Statistical analyses}

Heavy metal concentration in treated effluent was reported in $\mathrm{mg} \mathrm{L}^{-1}$, and heavy metal concentration in plant material was reported as $\mathrm{mg} \mathrm{kg}^{-1}$ dry weight and is mean of five replicates. Two-way analysis of variance (ANOVA) was conducted by using SPSS 16 package to determine the role of plant species and retention time on the removal of heavy metals. Duncan's multiple range test (DMRT at alpha $=0.05)$ was used to determine significant differences between mean values.

Accumulation of heavy metals has been calculated for $\mathrm{Cu}, \mathrm{Cd}, \mathrm{Cr}, \mathrm{Ni}, \mathrm{Fe}, \mathrm{Pb}$, and $\mathrm{Zn}$ in $P$. australis and T. latifolia grown individually and in association. Mass balance equation has revealed that the loss of heavy metals in wastewater was equivalent to the net accumulation of heavy metals in plant and loss of heavy metals in natural degradation. Mass balance of heavy metals was calculated using formula:

Net accumulation of heavy metal in all plants harvested from each experimental set $(\mathrm{mg})=($ Cin - Ceff $R) \times V$, where Cin $=$ average concentration of heavy metal in wastewater before treatment, Ceff $=$ average concentration of heavy metal in wastewater after treatment, $R=$ natural degradation heavy metal in unplanted culture, and $V=$ volume of the wastewater $(50 \mathrm{~L})$ used in each experimental set.

\section{Results and discussion}

Role of plants in the removal of heavy metals

Removal of $\mathrm{Cu}, \mathrm{Cd}, \mathrm{Cr}, \mathrm{Ni}, \mathrm{Fe}, \mathrm{Pb}$, and $\mathrm{Zn}$ through natural degradation, adsorption, and precipitation was 
Table 2 Removal of $\mathrm{Cu}, \mathrm{Cd}, \mathrm{Cr}, \mathrm{Ni}, \mathrm{Fe}, \mathrm{Pb}$, and $\mathrm{Zn}$ in P. australis, $T$. latifolia, their combination and reference set

\begin{tabular}{lllll}
\hline $\begin{array}{l}\text { Heavy } \\
\text { metal } \\
(\%)\end{array}$ & $\begin{array}{l}\text { Combination of } \\
\begin{array}{l}P . \text { australis } \text { and } \\
\text { T. latifolia }\end{array}\end{array}$ & P. australis & T. latifolia & $\begin{array}{l}\text { Reference } \\
\text { set }\end{array}$ \\
\hline $\mathrm{Cu}$ & $55.8 \pm 16.8$ & $50.8 \pm 19.0$ & $55.1 \pm 15.7$ & $16.0 \pm 8.3$ \\
$\mathrm{Cd}$ & $41.2 \pm 16.7$ & $44.2 \pm 12.1$ & $41.0 \pm 13.1$ & $22.7 \pm 18.4$ \\
$\mathrm{Cr}$ & $55.1 \pm 15.6$ & $49.0 \pm 14.8$ & $48.8 \pm 13.6$ & $18.9 \pm 12.3$ \\
$\mathrm{Ni}$ & $59.3 \pm 14.2$ & $58.0 \pm 13.7$ & $50.4 \pm 15.9$ & $19.6 \pm 8.8$ \\
$\mathrm{Fe}$ & $66.4 \pm 4.5$ & $65.1 \pm 6.6$ & $62.4 \pm 6.1$ & $9.3 \pm 3.8$ \\
$\mathrm{~Pb}$ & $48.8 \pm 17.2$ & $46.6 \pm 14.7$ & $46.6 \pm 14.7$ & $17.0 \pm 9.1$ \\
$\mathrm{Zn}$ & $62.9 \pm 8.7$ & $55.8 \pm 14.8$ & $59.3 \pm 19.9$ & $9.4 \pm 4.9$ \\
\hline
\end{tabular}

Values are the mean \pm standard deviation for $n=50$

evaluated with the help of reference experimental sets kept without plants, and results are shown in the Table 2. Experiment revealed the removal of very little quantity of heavy metals through natural degradation. Henceforth, keeping this in view, two aquatic plant species, i.e. $P$. australis and T. latifolia, were used for the efficient removal of heavy metals. The removal of $\mathrm{Cu}, \mathrm{Cd}, \mathrm{Cr}, \mathrm{Ni}, \mathrm{Fe}, \mathrm{Pb}$, and $\mathrm{Zn}$ was studied in P. australis and T. latifolia individually and in combination. In combination of the $P$. australis and T. latifolia, significant enhancement in the removal of $\mathrm{Cu}, \mathrm{Cd}, \mathrm{Cr}, \mathrm{Ni}, \mathrm{Fe}$, $\mathrm{Pb}$, and $\mathrm{Zn}$ (Table 2) over the values of reference experimental sets has been observed. The possible mechanism for the removal of heavy metals in planted culture might be due to the uptake of metals by plants and higher microbial degradation. Present trends of heavy metal removal is supported by similar findings of Brix (1994) and Ranieri et al. (2011). Therefore, present findings revealed the significant role of plants in the removal of $\mathrm{Cu}, \mathrm{Cd}, \mathrm{Cr}, \mathrm{Ni}, \mathrm{Fe}, \mathrm{Pb}$, and $\mathrm{Zn}$ from secondary treated effluent. Present findings are also supported by similar findings of some previous researchers for the removal of heavy metals (Khan et al. 2009; Mehra et al. 2000; Mishra et al. 2009; Mishra and Tripathi 2009; Sawidis et al. 1995; Upadhyay et al. 2007; Vymazal et al. 2007), organic materials, nutrients, pharmaceutical, and personal care products (Chang et al. 2012; Cui et al. 2011; Hamouri et al. 2007; Salvato and Borin 2010; Reyes-Contreras et al. 2012) from wastewater by aquatic plants.

When $P$. australis and T. latifolia were grown in combination, there is further increase in the removal of $\mathrm{Cr}, \mathrm{Fe}$, and $\mathrm{Zn}$ than the plants grown individually. The possible reason for enhanced removal of $\mathrm{Cr}, \mathrm{Fe}$, and $\mathrm{Zn}$ might be due to the fact that behaviour of plants is changed when grown in combination, which is known as synergistic effects of the plant species. Present findings are supported by similar report of Tripathi and Upadhayay (2003) for the removal of nitrogen and phosphorous from the secondary treated dairy effluent.

Removal of $\mathrm{Cr}, \mathrm{Ni}$, and $\mathrm{Fe}$ was significantly higher in $P$. australis culture than that of $T$. latifolia culture, whereas in T. latifolia culture removal of $\mathrm{Cu}, \mathrm{Cd}$, and $\mathrm{Zn}$ was higher. The possible reason would be that the selected plant species may have different uptake efficiency for the heavy metals. Similar findings of Mishra and Tripathi (2008), where significantly different removal of $\mathrm{Fe}, \mathrm{Cu}, \mathrm{Cd}, \mathrm{Cr}$, and $\mathrm{Zn}$ with the help of Pistia stratioties, Siprodela polyrrhiza and Eichhornia crassipes further supports the present observation. Synergetic effects were not observed for the removal of $\mathrm{Cu}, \mathrm{Cd}, \mathrm{Pb}$, and $\mathrm{Ni}$ when $P$. australis and T. latifolia were grown in combination. These findings were similar to those reported by Chang et al. (2012) for the removal of organic and inorganic pollutants.

The preferential order of heavy metal removal in the present study was $\mathrm{Fe}>\mathrm{Zn}>\mathrm{Ni}>\mathrm{Cu} \approx \mathrm{Cr}>\mathrm{Pb}>\mathrm{Cd}$ in P. australis, $\mathrm{Fe}>\mathrm{Zn}>\mathrm{Cu}>\mathrm{Ni}>\mathrm{Cr}>\mathrm{Pb}>\mathrm{Cd}$ in $T$. latifolia, and $\mathrm{Fe}>\mathrm{Zn}>\mathrm{Ni}>\mathrm{Cu} \approx \mathrm{Cr}>\mathrm{Pb}>\mathrm{Cd}$ in combination of both the plants (Table 2). Fe removal was highest followed by $\mathrm{Zn}, \mathrm{Ni}$, and $\mathrm{Cu}$. The possible reason might be the higher uptake of $\mathrm{Fe}, \mathrm{Zn}, \mathrm{Ni}$, and $\mathrm{Cu}$ due to their use in plants as essential micronutrients. Present findings were similar to those reported by Upadhyay et al. (2007).

High removal of $\mathrm{Pb}(36.0 \%), \mathrm{Cd}(33.0 \%)$, and $\mathrm{Cu}$ $(27.0 \%)$ in the present study as compared to the duckweed and algal system reported by Sekomo et al. (2012) indicates higher efficiency of $P$. australis and $T$. latifolia. However, Abhilash et al. (2009) reported higher removal of $\mathrm{Cd}(98 \%)$ in 30 days from synthetic water by Limnocharis flava grown in free-floating culture as compared to the present study (Table 2). The possible reason for higher $\mathrm{Cd}$ removal in the former may be due to longer retention time and differential uptake of heavy metals by different plant species. These findings revealed that plant species, retention time, and heavy metal concentration in the wastewater are the major factors affecting the removal of the heavy metals in the present study. Since retention time and heavy metal concentration in effluent were common factors in all the experimental sets hence, heavy metal removal totally depended on the type of plant species. Present findings are supported by similar findings of Marchand et al. (2010). 
Fig. 2 Removal of a $\mathrm{Cu}, \mathrm{Cd}$, and $\mathrm{Ni}$ and $\mathbf{b} \mathrm{Cr}, \mathrm{Fe}, \mathrm{Pb}$, and $\mathrm{Zn}$ in the combination of $P$. australis and T. latifolia culture
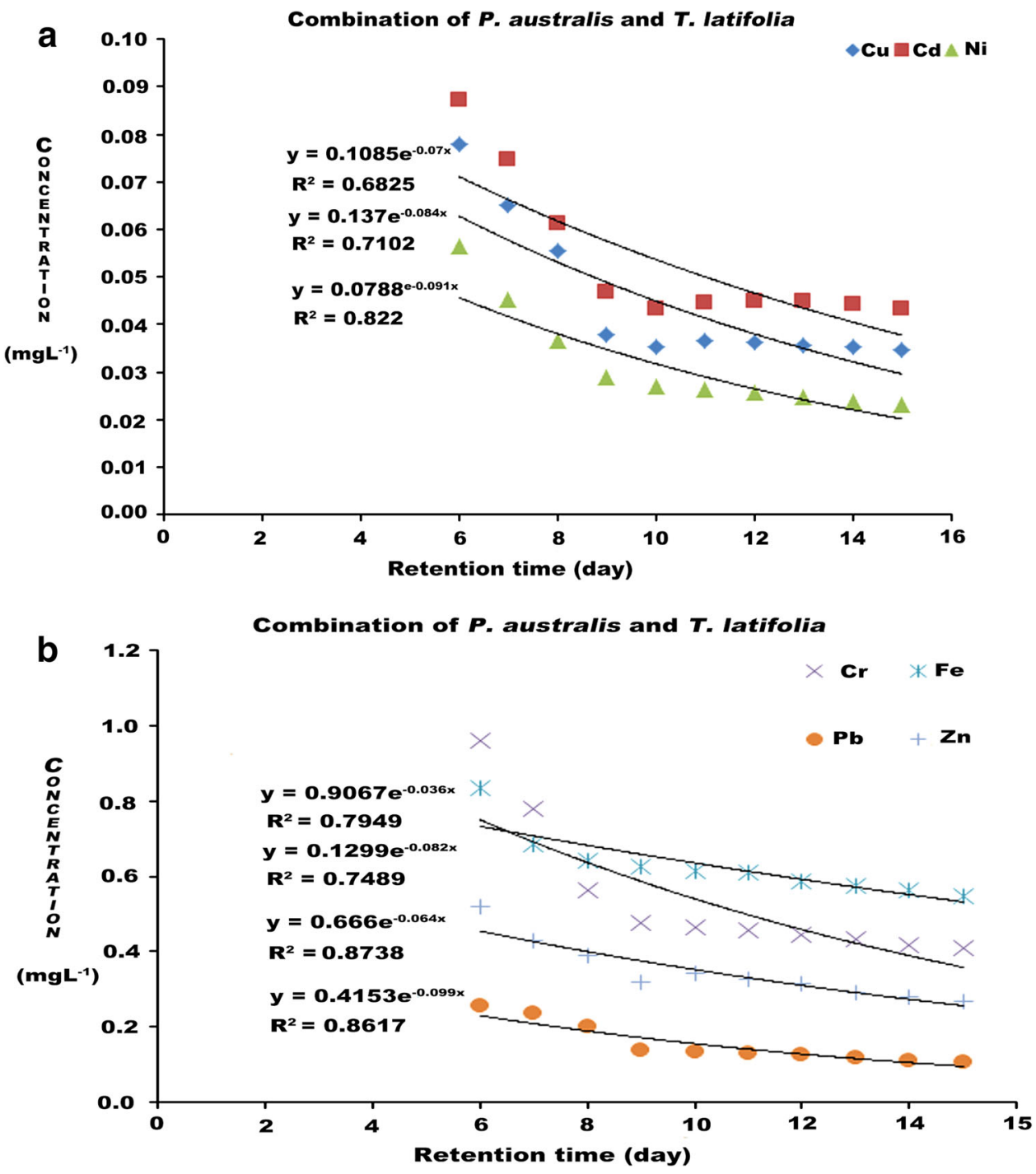

In this study, $P$. australis and T. latifolia have shown higher removal of $\mathrm{Cu}, \mathrm{Cd}, \mathrm{Cr}, \mathrm{Ni}, \mathrm{Fe}, \mathrm{Pb}$, and $\mathrm{Zn}$ without any visible injury. This might be due to the enhancement of antioxidative metabolism in the plants under metal stress conditions, which was supported by similar findings of Fediue and Erdei (2002) and Iannelli et al. (2002). Similar findings were also reported by Lyubenova and Schröder (2011) for the removal of As and Cd from wastewater by $T$. latifolia.

Relationship between retention time and removal of heavy metals

In the present study, continuous decrease in the concentration of $\mathrm{Cu}, \mathrm{Cd}, \mathrm{Cr}, \mathrm{Ni}, \mathrm{Fe}, \mathrm{Pb}$, and $\mathrm{Zn}$ in the wastewater observed up to 15 days when $P$. australis and T. latifolia grown in combination (Fig. 2a, b) indicates positive relationship of removal with retention time $(p<0.001)$. Similar findings by Mishra and Tripathi (2008) and Miretzky et al. (2004) support the present observation.

Accumulation and mass balance of heavy metals

The mean relative growth rate (on fresh weight basis) was found to be $0.67 \pm 0.01 \mathrm{~g} \mathrm{day}^{-1}$ plant $^{-1}$ for $P$. australis and $0.61 \pm 0.01 \mathrm{~g} \mathrm{day}^{-1}$ plant $^{-1}$ for T. latifolia. Clevering (1999) reported much lower relative growth rate $\left(0.12 \pm 0.004\right.$ day $\left.^{-1}\right)$ of $P$. australis than the present study. Higher relative growth rate in the present study might be due to the fact that in the present study, the fresh weight was considered. The dry matter production after exposure was $2.0 \pm 0.1 \mathrm{~g}$ per plant for $P$. australis and 
Table 3 Mass balance calculations of $\mathrm{Cu}, \mathrm{Cd}, \mathrm{Cr}, \mathrm{Ni}, \mathrm{Fe}, \mathrm{Pb}$, and $\mathrm{Zn}$ for P. australis, T. latifolia and their combination (mass per 15 days)

\begin{tabular}{|c|c|c|c|c|c|}
\hline Heavy metals & Plant sp. & Initial concentration (mg) & Concentration after treatment $(\mathrm{mg})$ & Net accumulation in plant (mg) & $R(\mathrm{mg})$ \\
\hline \multirow[t]{3}{*}{$\mathrm{Cu}$} & $\mathrm{Phr}+\mathrm{Ty}$ & $5.30 \pm 0.84$ & $1.74 \pm 0.19$ & $2.32 \pm 0.59$ & $1.24 \pm 0.54$ \\
\hline & $\mathrm{Phr}$ & $5.30 \pm 0.84$ & $1.89 \pm 0.15$ & $2.17 \pm 0.33$ & $1.24 \pm 0.54$ \\
\hline & Ty & $5.30 \pm 0.84$ & $2.13 \pm 0.125$ & $1.93 \pm 0.41$ & $1.24 \pm 0.54$ \\
\hline \multirow[t]{3}{*}{$\mathrm{Cd}$} & $\mathrm{Phr}+\mathrm{Ty}$ & $4.55 \pm 0.10$ & $2.17 \pm 0.08$ & $1.52 \pm 0.01$ & $0.86 \pm 0.21$ \\
\hline & $\mathrm{Phr}$ & $4.55 \pm 0.10$ & $2.08 \pm 0.23$ & $1.61 \pm 0.28$ & $0.86 \pm 0.21$ \\
\hline & Ty & $4.55 \pm 0.10$ & $2.27 \pm 0.15$ & $1.42 \pm 0.28$ & $0.86 \pm 0.21$ \\
\hline \multirow[t]{3}{*}{$\mathrm{Cr}$} & $\mathrm{Phr}+\mathrm{Ty}$ & $60.60 \pm 6.04$ & $20.40 \pm 1.98$ & $24.50 \pm 7.79$ & $15.70 \pm 7.88$ \\
\hline & $\mathrm{Phr}$ & $60.60 \pm 6.04$ & $24.63 \pm 0.50$ & $19.68 \pm 7.16$ & $15.70 \pm 7.88$ \\
\hline & Ty & $60.60 \pm 6.04$ & $24.90 \pm 1.56$ & $20.00 \pm 7.03$ & $15.70 \pm 7.88$ \\
\hline \multirow[t]{3}{*}{$\mathrm{Ni}$} & $\mathrm{Phr}+\mathrm{Ty}$ & $3.91 \pm 0.37$ & $1.15 \pm 0.05$ & $1.57 \pm 0.47$ & $1.19 \pm 0.16$ \\
\hline & $\mathrm{Phr}$ & $3.91 \pm 0.37$ & $1.14 \pm 0.07$ & $1.58 \pm 0.49$ & $1.19 \pm 0.16$ \\
\hline & Ty & $3.91 \pm 0.37$ & $1.42 \pm 0.104$ & $1.30 \pm 0.53$ & $1.19 \pm 0.16$ \\
\hline \multirow[t]{3}{*}{$\mathrm{Fe}$} & $\mathrm{Phr}+\mathrm{Ty}$ & $93.40 \pm 2.61$ & $27.40 \pm 0.74$ & $52.80 \pm 3.42$ & $13.20 \pm 2.13$ \\
\hline & $\mathrm{Phr}$ & $93.40 \pm 2.61$ & $27.20 \pm 2.56$ & $53.00 \pm 5.42$ & $13.20 \pm 2.13$ \\
\hline & Ty & $93.40 \pm 2.61$ & $30.60 \pm 1.29$ & $49.60 \pm 3.45$ & $13.20 \pm 2.13$ \\
\hline \multirow[t]{3}{*}{$\mathrm{Pb}$} & $\mathrm{Phr}+\mathrm{Ty}$ & $16.40 \pm 1.29$ & $5.27 \pm 0.77$ & $6.03 \pm 1.25$ & $5.10 \pm 0.22$ \\
\hline & $\mathrm{Phr}$ & $16.40 \pm 1.29$ & $5.40 \pm 0.22$ & $5.90 \pm 0.96$ & $5.10 \pm 0.23$ \\
\hline & Ty & $16.40 \pm 1.29$ & $6.30 \pm 0.27$ & $5.00 \pm 1.17$ & $5.10 \pm 0.22$ \\
\hline \multirow[t]{3}{*}{$\mathrm{Zn}$} & $\mathrm{Phr}+\mathrm{Ty}$ & $47.23 \pm 0.31$ & $13.40 \pm 1.75$ & $26.10 \pm 2.36$ & $7.73 \pm 0.91$ \\
\hline & $\mathrm{Phr}$ & $47.23 \pm 0.31$ & $15.40 \pm 0.65$ & $24.10 \pm 1.39$ & $7.73 \pm 0.91$ \\
\hline & Ty & $47.23 \pm 0.31$ & $12.10 \pm 1.64$ & $27.40 \pm 2.07$ & $7.73 \pm 0.91$ \\
\hline
\end{tabular}

$\mathrm{Phr}=$ Phragmites australis, Ty $=$ Typha latifolia, $\mathrm{R}=$ Concentration in reference set (without plant). Values are the mean of five replicates

Table 4 Mean concentrations of $\mathrm{Cu}, \mathrm{Cd}, \mathrm{Cr}, \mathrm{Ni}, \mathrm{Fe}, \mathrm{Pb}$, and $\mathrm{Zn}$ in $P$. australis and T. latifolia after 15 days of experiment

\begin{tabular}{lllll}
\hline $\begin{array}{l}\text { Heavy } \\
\text { metals }\end{array}$ & $\begin{array}{l}\text { Plant } \\
\text { sp. }\end{array}$ & \multicolumn{1}{l}{$\begin{array}{l}\text { Initial } \\
\text { concentration } \\
\left(\mathrm{mg} \mathrm{kg}^{-1}\right)\end{array}$} & $\begin{array}{l}\text { Concentration } \\
\text { after treatment } \\
\left(\mathrm{mg} \mathrm{kg}^{-1}\right)\end{array}$ & $\begin{array}{l}\text { Net } \\
\text { accumulation } \\
\text { in plant } \\
\left(\mathrm{mg} \mathrm{kg}^{-1}\right)\end{array}$ \\
\hline $\mathrm{Cu}$ & $\mathrm{Phr}$ & $6.74 \pm 0.21$ & $6.78 \pm 0.21$ & $0.04 \pm 0.01$ \\
$\mathrm{Cd}$ & $\mathrm{Ty}$ & $6.86 \pm 0.03$ & $6.90 \pm 0.04$ & $0.04 \pm 0.04$ \\
& $\mathrm{Phr}$ & $1.03 \pm 0.02$ & $1.06 \pm 0.02$ & $0.03 \pm 0.01$ \\
$\mathrm{Cr}$ & $\mathrm{Phr}$ & $1.05 \pm 0.03$ & $1.08 \pm 0.02$ & $0.03 \pm 0.01$ \\
& $\mathrm{Ty}$ & $2.03 \pm 0.05$ & $2.42 \pm 0.13$ & $0.41 \pm 0.14$ \\
$\mathrm{Ni}$ & $\mathrm{Phr}$ & $0.78 \pm 0.12$ & $0.82 \pm 0.12$ & $0.04 \pm 0.03$ \\
& $\mathrm{Ty}$ & $0.98 \pm 0.01$ & $1.00 \pm 0.01$ & $0.03 \pm 0.01$ \\
$\mathrm{Fe}$ & $\mathrm{Phr}$ & $73.7 \pm 3.72$ & $74.72 \pm 3.76$ & $1.06 \pm 0.11$ \\
& $\mathrm{Ty}$ & $71.60 \pm 0.86$ & $72.59 \pm 0.81$ & $0.99 \pm 0.07$ \\
$\mathrm{~Pb}$ & $\mathrm{Phr}$ & $2.47 \pm 0.15$ & $2.59 \pm 0.15$ & $0.12 \pm 0.02$ \\
& $\mathrm{Ty}$ & $5.56 \pm 0.07$ & $5.66 \pm 0.07$ & $0.10 \pm 0.02$ \\
$\mathrm{Zn}$ & $\mathrm{Phr}$ & $50.58 \pm 0.11$ & $51.06 \pm 0.11$ & $0.48 \pm 0.03$ \\
& $\mathrm{Ty}$ & $51.16 \pm 0.96$ & $51.71 \pm 0.96$ & $0.55 \pm 0.04$ \\
\hline
\end{tabular}

$\mathrm{Phr}=$ Phragmites australis, Ty = Typha latifolia. Values are the mean of five replicates
$1.8 \pm 0.1 \mathrm{~g}$ per plant for T. latifolia. Net accumulation of $\mathrm{Cu}, \mathrm{Cd}, \mathrm{Cr}, \mathrm{Ni}, \mathrm{Fe}, \mathrm{Pb}$, and $\mathrm{Zn}$ is the increase in the concentration of these heavy metals over their initial concentrations in the whole plant body. Net accumulation of $\mathrm{Cu}$, $\mathrm{Cr}, \mathrm{Ni}, \mathrm{Fe}$, and $\mathrm{Zn}$ was higher when $P$. australis and $T$. latifolia grown in combination as compared to their individual culture (Table 3). Higher net accumulation of $\mathrm{Cu}$, $\mathrm{Cd}, \mathrm{Cr}, \mathrm{Ni}, \mathrm{Fe}$, and $\mathrm{Pb}$ in $P$. australis than that of T. latifolia (Table 4) revealed that $P$. australis has higher accumulative affinities towards these metals. The preferential order of net accumulation of heavy metals was noted as

$\mathrm{Fe}>\mathrm{Zn}>\mathrm{Cr}>\mathrm{Pb}>\mathrm{Ni}>\mathrm{Cu}>\mathrm{Cd}$ in $P$. australis, $\mathrm{Fe}>\mathrm{Zn}>\mathrm{Cr}>\mathrm{Pb}>\mathrm{Cu}>\mathrm{Ni}>\mathrm{Cd}$ in T. latifolia and $\mathrm{Fe}>\mathrm{Zn}>\mathrm{Cr}>\mathrm{Pb}>\mathrm{Cu}>\mathrm{Ni}>\mathrm{Cd}$ in combination of $P$. australis and T. latifolia. The decreasing order of heavy metal accumulation in the whole plant after 15 days of exposure $\left(\mathrm{mg} \mathrm{kg}^{-1}\right.$ dry weight) was noted as $\mathrm{Fe}$ $(1,494.4)>\mathrm{Zn}(1,021.1)>\mathrm{Cu}(135.6)>\mathrm{Pb}(51.8)>\mathrm{Cr}$ (48.4) $>\mathrm{Ni}$ (16.4) $>\mathrm{Cd}$ (21.2) for P. australis. In T. latifolia, the accumulation of metal in the whole plant after 15 days of exposure in $\mathrm{mg} \mathrm{kg}^{-1}$ dry weight was highest for $\mathrm{Fe}(1,451.8)$ followed by $\mathrm{Zn}(1,034.2), \mathrm{Pb}$ (113.2), $\mathrm{Cr}$ (48.4), Ni (20.0), and lowest for Cd (21.6). Similar trends 
of heavy metal accumulation, i.e. $\mathrm{Fe}>\mathrm{Zn}>\mathrm{Ni}>$ $\mathrm{Cu}>\mathrm{Mn}>\mathrm{Cr}>\mathrm{Pb}>\mathrm{Cd}$ and $\mathrm{Fe}>\mathrm{Zn}>\mathrm{Ni}>\mathrm{Mn}>$ $\mathrm{Cr}>\mathrm{Cu}>\mathrm{Pb}>\mathrm{Cd}$ in roots and fronds of Azolla caroliniaana (water fern) grown in fly ash effluent also support the present findings (Pandey 2012). Similar findings were also reported by Marchand et al. (2010), Khan et al. (2009), Sekomo et al. (2012), and Upadhyay et al. (2007).

The possible reason for higher accumulation of Fe in $P$. australis and T. latifolia might be due to the fact that $\mathrm{Fe}$ is an essential micronutrient and highly required for plant metabolism. These findings revealed that variations in heavy metal uptake by these plants might be due to differential plant growth rate and heavy metal uptake affinities. Similar findings were also reported by Marchand et al. (2010), Khan et al. (2009), Sekomo et al. (2012), and Upadhyay et al. (2007).

In this study, higher concentration of $\mathrm{Cu}, \mathrm{Cr}, \mathrm{Ni}, \mathrm{Fe}, \mathrm{Pb}$, and $\mathrm{Zn}$ (Table 3 ) in $P$. australis and T. latifolia grown in combination than the surrounding water indicated that $P$. australis and $T$. latifolia grown in association were appropriate for the accumulation of these heavy metals. Similar findings of Sasmaz et al. (2008) support the present observations.

Mass balance equation revealed that the loss of $\mathrm{Cu}, \mathrm{Cd}$, $\mathrm{Cr}, \mathrm{Ni}, \mathrm{Fe}, \mathrm{Pb}$, and $\mathrm{Zn}$ in the wastewater was equivalent to their net accumulations in the plant and loss through natural degradation (Table 3). These findings revealed that plant uptake and natural degradation of the heavy metals are the two main processes for their removal in the present study.

\section{Conclusion}

In the present study, the heavy metal removal capacities of the $P$. australis and $T$. latifolia grown individually and in combination were tested. Significantly higher removal for $\mathrm{Cr}$, Fe, and $\mathrm{Zn}$ when grown in combination than that of their individual culture signified the change in the behaviour of plants when grown in combination, which is known as synergistic effects of the plant species. These findings revealed significant effect of $P$. australis and $T$. latifolia on the removal $\mathrm{Cr}, \mathrm{Fe}$, and $\mathrm{Zn}$ when grown combination. The observations also revealed that there was a positive and significant relationship between the removal of $\mathrm{Cu}, \mathrm{Cd}, \mathrm{Cr}$, $\mathrm{Ni}, \mathrm{Fe}, \mathrm{Pb}$ and $\mathrm{Zn}$, and retention time. Highest removal at 15 th day of retention time $(p<0.001)$ indicates that 15-day treatment is sufficient for maximum removal. Preferential order of heavy metals removal indicates higher affinities of $\mathrm{Fe}$ towards plants followed by $\mathrm{Zn}>\mathrm{Cr}>\mathrm{Pb}>\mathrm{Cu}>\mathrm{Ni}$ and least in the case of $\mathrm{Cd}$. Mass balance analysis further revealed that loss of $\mathrm{Cu}, \mathrm{Cd}$,
$\mathrm{Cr}, \mathrm{Ni}, \mathrm{Fe}, \mathrm{Pb}$, and $\mathrm{Zn}$ from wastewater was equivalent to their uptake by plants and loss through natural degradation. $P$. australis showed higher accumulative capacities for $\mathrm{Cu}$, $\mathrm{Cd}, \mathrm{Cr}, \mathrm{Ni}, \mathrm{Fe}$, and $\mathrm{Pb}$ than those of $T$. latifolia.

Henceforth, $P$. australis and T. latifolia grown in association may be better option for the removal of heavy metals from secondary treated effluent in the tropical environment.

Acknowledgments The authors thank the University Grant Commission (UGC) (Ref. No. Bot./2009-10/Regd.Sept.2009/14/11/09), India, for financial support. The authors are also thankful to the Head, Department of Botany, Banaras Hindu University for providing laboratory facilities.

\section{References}

Abhilash PC, Pandey VC, Srivastava P, Rakesh PS, Chandran S, Singh N, Thomas AP (2009) Phytofiltration of cadmium from water by Limnocharis flava (L.) Buchenau grown in free-floating culture system. J Hazard Mater 170(2-3):791-797

Allende KL, Fletcher TD, Sun G (2011) Enhancing the removal of arsenic, boron and heavy metals in subsurface flow constructed wetlands using different supporting media. Water Sci Technol 63(11):2612-2618

APHA, AWWA, WEF (2005) Standard methods for the examination of water and wastewater. 21st edn. American Public Health Association/American Water Works Association/Water Environment Federation, USA

Augustynowicz J, Grosick M, Fajerska EH, Lekka M, Waloszek A, Koloczek H (2010) Chromium (VI) bioremediation by aquatic macrophyte Callitriche colphocarpa Sendtn. Chemosphere 79:1077-1083

Aziz HA, Adlan MN, Ariffin KS (2008) Heavy metals (Cd, Pb, Zn, $\mathrm{Ni}, \mathrm{Cu}$ and $\mathrm{Cr}(\mathrm{III})$ ) removal from water in Malaysia: post treatment by quality limestone. Bioresour Technol 99(6):1578-1583

Badkoubi A, Ganjidoust H, Ghaderi A, Rajabi A (1998) Performance of a subsurface constructed wetland in Iran. Water Sci Technol $38: 345-350$

Bonanno G, Giudice RL (2010) Heavy metal bioaccumulation by the organs of Phragmites australis (common reed) and their potential use as contamination indicators. Ecol Indic 10:639-645

Bonano GA (2012) Arundo donax as a potential biomonitor of trace element contamination in water and sediment. Ecotoxicol Environ Saf 80:20-27

Brix H (1994) Functions of macrophytes in constructed wetlands. Water Sci Technol 29(4):71-78

Caselles-Osorio A, Garcia J (2007) Impact of different feeding strategies and plant presence on the performance of shallow horizontal subsurface-flow constructed wetlands. Sci Total Environ 378(3):253-262

Chang JJ, Wu SQ, Dai YR, Liang W, Wu ZB (2012) Treatment performance of integrated vertical-flow constructed wetland plots for domestic wastewater. Ecol Eng 44:152-159

Clevering OA (1999) Between- and within-population differences in Phragmites australis 1. The effects of nutrients on seedling growth. Oecologia 121:447-457

Cohen RRH (2006) Use of microbes for cost reduction of metal removal from metals and mining industry water streams. J Clean Prod 14(12-13):1146-1157 
CPCB (1993) General standards for discharge of environmental pollutants. Part A: effluents. Central Pollution Control Board, New Delhi

Cui LH, Zhu XZ, Ouyang Y, Chen Y, Yang FL (2011) Total phosphorous removal from domestic wastewater with Cyperus alternifolius in vertical-flow constructed wetlands at the microcosm level. Int J Phytoremediation 13(7):692-701

Ewan KB, Pamphlett R (1996) Increased inorganic mercury in spinal motor neurons following chelating agents. Neurotoxicology 17:343-349

Fediue E, Erdei L (2002) Physiological and biochemical aspects of cadmium toxicity and protective mechanisms induced in Phragmites australis and Typha latifolia. J Plant Physiol 159:265-271

Ghemandi A, Bixio D, Thoeye C (2007) The role of free water surface constructed wetlands as polishing step in municipal wastewater reclamation and reuse. Sci Total Environ 380(1-3):247-258

Hamouri BEI, Nazih E, Lahjouj J (2007) Subsurface-horizontal flow constructed wetland for sewage treatment under Moroccan climate conditions. Desalination 215:153-158

Hua GF, Li L, Zhao YQ, Zhu W, Shen JQ (2013) An integrated model of substrate clogging in vertical flow constructed wetlands. J Environ Manage 119:67-75

Iannelli MA, Pietrini F, Fiore L, Petrilli L, Massacci A (2002) Antioxidant response to cadmium in Phragmites australis plants. Plant Physiol Biochem 40:977-982

Jacob DL, Otte ML (2004) Influence of Typha latifolia and fertilization as metal mobility in two different $\mathrm{Pb}-\mathrm{Zn}$ mine tailings types. Sci Total Environ 333:9-24

Kalra YP (1998) Reference methods for plant analysis. CRC Press, Taylor and Francis Group, Boca Raton, FL

Khan S, Ahmad I, Shah MT, Rehman S, Khaliq A (2009) Use of constructed wetland for the removal of heavy metals from industrial wastewater. J Environ Manage 90:3451-3457

Langergraba $G$ (2005) The role of plant uptake on the removal of organic matter and nutrients in subsurface flow constructed wetlands: a simulation study. Water Sci Technol 51(9):213-223

Lyubenova L, Schröder P (2011) Plants for waste water treatmenteffects of heavy metals on the detoxification system of Typha latifolia. Bioresour Technol 102(2):996-1004

Maine MA, Suňe N, Hadad H, Sánchez G, Bonetto C (2009) Influence of vegetation on the removal of heavy metals and nutrients in a constructed wetland. J Environ Manage 90:355-363

Marchand L, Mench M, Jacob DL, Otte ML (2010) Metal and metalloid removal in constructed wetlands, with emphasis on the importance of plants and standardized measurements: a review. Environ Pollut 158(12):3447-3461

Mehra A, Farago ME, Banerjee DK (2000) A study of Eichhornia crassipes growing in the overbank and floodplain soils of the river Yamuna in Delhi, India. Environ Monitor Assess 60:25-45

Mench M, Schwitzguébel JP, Schröder P, Bert V, Gawronski S, Gupta S (2009) Assessment of successful experiments and limitations of phytotechnologies: contaminant uptake, detoxification and sequestration, and consequences for food safety. Environ Sci Pollut Res 16:876-900

Miretzky P, Saralegui A, Cirelli AF (2004) Aquatic macrophytes potential for the simultaneous removal of heavy metals (Buenos Aires, Argentina). Chemosphere 57:997-1005

Mishra VK, Tripathi BD (2008) Concurrent removal and accumulation of heavy metals by three aquatic macrophytes. Bioresour Technol 99:7091-7097

Mishra VK, Tripathi BD (2009) Accumulation of chromium and zinc from aqueous solutions using water hyacinth (Eichhornia crassipes). J Hazard Mater 164:1059-1063
Mishra VK, Tripathi BD, Kim KH (2009) Removal and accumulation of mercury by aquatic macrophytes from an open cast coal mine effluent. J Hazard Mater 172:749-754

Moore JW (1990) Inorganic contaminants of surface water research and monitoring priorities. Springer, New York

Ong SA, Uchiyama K, Inadama D, Ishida Y, Yamagiwa K (2010) Performance evaluation of laboratory scale up-flow constructed wetlands with different designs and emergent plants. Bioresour Technol 101(19):7239-7244

Pandey VC (2012) Phytoremediation of heavy metals from fly ash pond by Azolla caroliniana. Ecotoxicol Environ Saf 82:8-12

Rai PK, Tripathi BD (2008) Heavy metals in industrial wastewater, soil and vegetables in Lohta village, India. Toxicol Environ Chem 90(2):247-257

Ranieri E (2012) Chromium and nickel control in full and small-scale sub superficial flow constructed wetlands. Soil Sediment Contam 21(7):802-814

Ranieri E, Paola V, Young TM (2011) Paracetamol removal in subsurface flow constructed wetlands. J Hydrol 404:130-135

Reyes-Contreras C, Hijosa-Valsero M, Sidrach-Cardona R, Bayona JM, Bécares E (2012) Temporal evaluation in PPCP removal from urban wastewater by constructed wetlands by different configuration: a medium-term study. Chemosphere 88(2):161-167

Saeed T, Sun G (2012) A review on nitrogen and organics removal mechanisms in subsurface flow constructed wetlands: dependency on environmental parameters, operating conditions and supporting media. J Environ Manage 112:429-448

Salvato M, Borin M (2010) Effect of different macrophytes in abating nitrogen from a synthetic wastewater. Ecol Eng 36:1222-1231

Sasmaz A, Obek E, Hasar H (2008) The accumulation of heavy metals in Typha latifolia L. grown in a stream carrying secondary effluent. Ecol Eng 33:278-284

Sawidis T, Chettri MK, Zachariadis GA, Stratis JA (1995) Heavy metals in aquatic plants and sediments from water systems in Macedonia, Greece. Ecotoxicol Environ Saf 32:73-80

Sekomo CB, Rousseau DPL, Saleh SA, Lens PNL (2012) Heavy metal removal in duckweed and algae ponds as a polishing step for textile wastewater treatment. Ecol Eng 44:102-110

Tang X, Scholz M, Eke PE, Huang S (2010) Nutrient removal as a function of benzene supply whining vertical-flow constructed wetlands. Environ Technol 31(6):681-691

Tripathi BD, Upadhyay AR (2003) Dairy effluent polishing by aquatic macrophytes. Water Air Soil Poll 43(1-4):377-385

Upadhyay AR, Mishra VK, Pandey SK, Tripathi BD (2007) Biofiltration of secondary treated municipal wastewater in a tropical city. Ecol Eng 30:9-15

Valipour A, Raman VK, Ghole VS (2009) A new approach in wetland systems for domestic wastewater treatment using Phragmites sp. Ecol Eng 35:1797-1803

Vymazal J (2005) Removal of heavy metals in a horizontal subsurface flow constructed wetland. J Environ Sci Health A Tox Hazard Subst Environ Eng 40(6-7):1369-1379

Vymazal J, Švehla J, Kröpfelova' L, Chrastny' V (2007) Trace metals in Phragmites australis and Phalaris arundinacea growing in constructed and natural wetlands. Sci Total Environ 380:154-162

Vymazal J, Kröpfelova' L, Švehla J, Chrastny' V, Š tı'chova J (2009) Trace elements in Phragmites australis growing in constructed wetlands for treatment of municipal wastewater. Ecol Eng 35:303-309

Wen Y, Chen Y, Zheng N, Yang D, Zhou Q (2010) Effects of plant biomass on nitrate removal and transformation of carbon sources in subsurface flow constructed wetlands. Bioresour Technol 101(19):7286-7292

Wojciechowska E, Waara S (2011) Distribution and removal efficiency of heavy metals in two constructed wetlands treating landfill leachate. Water Sci Technol 64(8):1597-1606 
Xue PY, Li GX, Liu WJ, Yan CZ (2010) Copper uptake and translocation in a submerged aquatic plant Hydrilla verticillata (Lf.) Royle. Chemosphere 81:1098-1103

Ye ZH, Baker AJM, Wong MH, Wilis AJ (1997) Zinc, lead and cadmium tolerance, uptake and accumulation by the common reed, Phragmites australis (Cav.) Trin. ex. Steudel. Ann Bot 80:363-370

Zhang DQ, Gersberg RM, Hua T, Zhu J, Tuan NA (2012) Pharmaceutical removal in tropical subsurface flow constructed wetlands in varying hydraulic loading rates. Chemosphere 87(3):273-277 